\title{
RELEVANSI POLITIK IDENTITAS PEMILIH MUSLIM DALAM PEMILIHAN GUBERNUR SUMATRA UTARA TAHUN 2018
}

\author{
Dharma Kelana Putra ${ }^{1 *}$ \\ ${ }^{1}$ Balai Pelestarian Nilai Budaya Aceh, Banda Aceh, Indonesia.
}

\section{ARTICLE INFORMATION}

Submitted : 19 August 2019

Review : 04 September 2019

Accepted : 27 November 2019

Available online: December 2019

\section{KEYWORDS}

Politics of Identity; Religion; Muslim Voters; Election of Governor; North Sumatra

\section{CORRESPONDENCE}

*E-mail:dharma.kelana@kemdikbud.go.id

\section{A. PENDAHULUAN}

S ejak merdeka tahun 1945, Indonesia telah melalui serangkaian sejarah panjang penerapan demokrasi dalam sistem pemerintahan, mulai dari demokrasi liberal, demokrasi parlementer, sampai kepada demokrasi pancasila dalam bentuknya yang sekarang (Purnaweni, 2004: 181). Demokrasi sendiri secara sederhana diartikan sebagai bentuk pemerintahan dimana setiap warga negara memiliki hak yang sama untuk menentukan nasibnya. Demokrasi berasal dari kata dalam bahasa Yunani demos yang berarti rakyat dan kratos yang artinya kekuasaan, yang kemudian menjadi demokratia atau kekuasaan rakyat.

Dalam demokrasi pemimpin dipilih oleh rakyat, baik secara langsung maupun tidak langsung (Purnaweni, 2004; Ma'arif, 2012; Fikri dan Oktario, 2018). Proses ini merupakan akhir dari sesuatu yang lama sekaligus menjadi awal dari sesuatu yang baru bagi rakyat, sehingga tak jarang proses pergantian kepemimpinan ini dianggap sebagai pesta demokrasi oleh berbagai kalangan. Kemenangan seorang pemimpin seyogyanya merupakan kemenangan bagi rak-

\begin{abstract}
A B S T R A C T
The similarity of identity such as religion and ethnicity as a primordial aspect becomes a preference in choosing a leader not based on their capability. In the election of the Governor of North Sumatra in 2018, identity politics tended to strengthen in Muslim voters, especially in terms of religion, indigenous issues and natives. This practics of identity politics resulted in a victory for the couple Edy RahmayadiMusa Rajeckshah (Islam-Islam). The main question in this study is why identity politics is still relevant to be used by Muslim voters in the Election of Governor of North Sumatra in 2018. The study was conducted with a qualitative descriptive method, in which all data were collected through library studies and internet searching. This study concludes that Muslim voters see identity politics still relevant to use in choosing leaders because they consider Muslims have to be led by leaders who care about Islam. This understanding emerged from previous experiences in DKI Jakarta, namely the Al Maidah 51 incident by Ahok and discriminatory practices against Muslims when led by the non-Muslims and the Muslims who did not care about Islam in various regions in Indonesia.
\end{abstract}

yatnya, sebab pemimpin terpilih merupakan hasil akumulasi dari suara terbanyak atau pilihan mayoritas.

Penerapan pemilihan pemimpin dalam sistem demokrasi di berbagai belahan dunia memiliki dinamika yang berbeda-beda. Di negara-negara yang homogen misalnya, preferensi dalam memilih pemimpin lebih dititik beratkan pada isu apa yang ia bawa, untuk kepentingan siapa dan bagaimana ia akan menjalankan roda kepemimpinannya setelah ia terpilih. Sementara, di negara-negara yang penduduknya heterogen, faktor identitas seperti etnis, agama, ras, warna kulit, usia, penampilan, budaya, dan bahasa menjadi aspek primordial yang sangat menentukan keberpihakan seseorang terhadap calon pemimpin yang akan ia pilih (Maarif, 2012; Xiaomei, 2014). Pelibatan aspek primordial dalam demokrasi untuk mengarahkan keberpihakan berdasarkan identitas tertentu disebut dengan politik identitas.

Polemik yang kemudian muncul adalah apakah praktik politik identitas baik atau buruk jika dalam demokrasi di Indonesia? Terkait dengan hal ini, ada perbedaan pendapat di kalangan akademisi, dimana sebagian mengata- 
kan bahwa politik identitas merupakan indikator primordialitas karena memilih pemimpin bukan berdasarkan kapasitas melainkan atas dasar identitas, sementara sebagian lainnya mengatakan baik karena pemimpin yang terpilih akan mengutamakan kepentingan rakyat banyak sebagai kelompok mayoritas (Caplan, 2008; Haboddin, 2012; Ma'arif, 2012; Burhan dan Sani, 2013; Faraidiany, 2016; Fikri dan Octario, 2018).

Di Indonesia khususnya di Sumatra Utara, politik identitas masih menjadi praktik politik yang populer di kalangan elit, dan dukungan dari kelompok mayoritas itu sendiri masih menjadi dambaan para politisi untuk memenangi suatu kontestasi. Dalam kasus pemilihan Gubernur Sumatra Utara tahun 2018 lalu misalnya, dukungan kelompok yang diperebutkan berasal dari etnis Jawa dan umat Islam sebagai mayoritas. Sebagaimana yang disajikan pada tabel berikut:

Tabel 1. Komposisi Penduduk Sumatra Utara Berdasarkan Etnis Tahun 2018

\begin{tabular}{lcc}
\hline \multicolumn{1}{c}{ Etnis } & Populasi & $\%$ \\
\hline Jawa & 4.749 .295 & 33,3 \\
Batak Toba & 2.738 .332 & 19,2 \\
Tionghoa & 1.511 .788 & 10,6 \\
Mandailing & 1.340 .642 & 9,4 \\
Minangkabau & 1.183 .758 & 8,3 \\
Melayu & 898.515 & 6,3 \\
Karo & 599.010 & 4,2 \\
Aceh & 399.340 & 2,8 \\
Simalungun & 85.573 & 0,6 \\
Nias & 98.409 & 0,7 \\
Pak-Pak & 98.409 & 0,7 \\
Lain-lain & 559.076 & 3,9 \\
\hline Jumlah & 14.262 .147 & 100,0 \\
\hline Sumber: Data Primer & &
\end{tabular}

Sementara jumlah penduduk berdasarkan agama dapat dilihat pada tabel berikut:

Tabel 2. Komposisi Penduduk Sumatra Utara Berdasarkan Agama Tahun 2018

\begin{tabular}{lcc}
\hline \multicolumn{1}{c}{ Agama } & Populasi & $\%$ \\
\hline Islam & 9.425 .734 & 66,1 \\
Protestan & 3.855 .729 & 27,0 \\
Katolik & 566.914 & 4,0 \\
Hindu & 16.088 & 0,1 \\
Budha & 333.475 & 2,3 \\
Lainnya & 64.207 & 0,5 \\
\hline Jumlah & 14.262 .147 & 100,0 \\
\hline Sumber: Data Primer & &
\end{tabular}

237 | P a $\mathrm{g} \mathrm{e}$

https://doi.org/10.25077/ jantro.v22.n2.p236-244.2019
Dari dua tabel di atas, diketahui bahwa kelompok etnis Jawa memiliki proporsi $33,3 \%$ dari seluruh populasi (4.749.295 jiwa) sementara pemeluk agama Islam tercatat dengan proporsi sebesar $66,1 \%$ dari seluruh populasi $(9.425 .734$ jiwa). Secara kuantitatif, ini menjadikan dua kelompok identitas ini sebagai basis dukungan yang potensial untuk mendulang suara. Satu hal yang menarik adalah, kedua calon Gubernur yakni Edy Rahmayadi dan Djarot Syaiful Hidayat bukan kelahiran Sumatra Utara, tetapi mereka sama-sama beragama Islam, dan sama-sama berdarah Jawa. Sementara wakilnya sama-sama berasal dari Sumatra Utara, hanya saja yang satu beragama Islam (Musa Rajeckshah) dan satu lagi beragama Kristen (Sihar Sitorus).

Pengamatan awal yang dilakukan terhadap beberapa media daring memperlihatkan bahwa politik identitas mewarnai persaingan yang terjadi di antara keduanya. Pendukung Edi Rahmayadi dan Musa Rajeckshah misalnya, mereka cenderung menyampaikan agar umat Islam memilih pemimpin muslim yang mau memperjuangkan agama Islam. Sementara, pendukung Djarot dan Sihar Sitorus menyampaikan pesan agar para pemilih tidak menjadikan persamaan identitas etnis maupun agama sebagai preferensi dalam memilih pemimpin. Namun di sisi lain, para pendukung Djarot dan Sihar juga memanfaatkan latar belakang keduanya untuk memperoleh dukungan suara dari pemilih beretnis Jawa dan Batak $^{\uparrow}$, yang juga sebagian besar adalah non muslim ${ }^{2}$. Reproduksi politik identitas yang ada di ruang publik seolah menciptakan konstruksi bahwa pemilihan Gubernur Sumatra Utara tahun 2018 adalah pertarungan antara kelompok Islam dan Non Muslim.

Dari konstruksi ini, jika diasumsikan seluruh pemilih non Muslim mendukung pasangan Djarot dan Sihar Sitorus sebanyak 33,9\%, maka mereka membutuhkan strategi kampanye untuk memperoleh suara pemilih muslim sebanyak $20 \%$ agar menang dalam pemilihan. Di sisi lain, pasangan Edi Rahmayadi dan Musa Rajeckshah membutuhkan strategi agar suara pemilih Muslim tidak beralih ke lawan politik mereka.

Hasil akhir yang diperoleh kemudian adalah kemenangan bagi pasangan Edy Rahmayadi dan Musa Rajeckshah, dengan perolehan suara $3.291 .137(57,58 \%)$. Strategi yang digunakan oleh pendukung Edi Rahmayadi dan Musa Rajeckshah berhasil mempertahankan dukungan suara pemilih muslim, dengan menyisakan

\footnotetext{
1 Rujuk pada tautan berikut: https://medan.tribunnews. com/2018/05/23/persaudaraan-jawa-batak-tegaskanmenangkan-djarot-sihar

2 Rujuk pada tautan berikut: https://news.solopos.com/ read/20180628/496/924891/faktor-kekalahan-djarot-siharmirip-ahok-djarot-di-pilkada-jakarta
} 
perolehan suara Djarot dan Sihar sebesar $2.424 .960(42,42 \%)^{3}$.

Ketatnya dinamika persaingan antara kedua pasang calon dalam memperebutkan suara pemilih muslim dan nuansa politik identitas yang mewarnainya menjadi asalan mengapa penelitian ini menarik untuk dilakukan. Atas dasar itu, penelitian ini bertujuan untuk mengungkap dan mendeskripsikan tentang mengapa politik identitas masih relevan digunakan oleh pemilih muslim dalam Pemilihan Gubernur Sumatra Utara Tahun 2018, kemudian bagaimana sebenarnya bentuk Politik Identitas yang digunakan oleh pemilih Muslim dalam pemilihan Gubernur Sumatra Utara Tahun 2018.

\section{B. METODE}

$\mathrm{M}$ etode yang digunakan dalam penelitian ini adalah metode kualitatif tipe deskriptif, yang bertujuan untuk menggambarkan secara tepat sifat-sifat suatu individu, keadaan, gejala atau kelompok tertentu di dalam masyarakat (Suparlan, 1994). Metode ini digunakan karena dianggap sesuai dengan tujuan penelitian, yang hanya terbatas pada upaya untuk mendeskripsikan mengapa politik identitas masih relevan digunakan dan bagaimana sebenarnya bentuk politik identitas yang digunakan oleh pemilih muslim dalam Pemilihan Gubernur Sumatra Utara tahun 2018.

Seluruh data diperoleh dari hasil penelusuran internet (internet searching) dan studi kepustakaan untuk mencari data tentang hal-hal atau variabel yang ingin diteliti baik berupa buku, laman berita, dan artikel jurnal maupun web site. Media daring menjadi sumber data utama karena lebih mudah diakses, konten yang singkat dan mudah dipahami, serta lebih interaktif karena disertai kolom komentar dari para pembacanya.

\section{HASIL DAN PEMBAHASAN}

\section{Identitas Politik dan Politik Identitas}

K onsep politik identitas pada dasarnya berbeda dengan konsep identitas politik, tetapi keduanya mengakar pada konsep yang sama yakni identitas. Secara harfiah, identitas sendiri berasal dari kata dalam bahasa latin "idem", yang artinya "sama", sedangkan secara konseptual, identitas merujuk pada identitas bersama, termasuk di dalamnya pengakuan atas keberadaan, penerimaan, dan afiliasi terhadap sebuah subjek (Xiaomei, 2014). Baik identitas politik maupun politik identitas sama-sama menempatkan seseorang pada sikap politik tertentu dan keberpihakannya berdasarkan kon-

\footnotetext{
3 Rujuk pada tautan berikut: https://nasional. kompas.com/read/2018/07/11/16345571/infografik-petakemenangan-pilkada-Sumatra-utara-2018
}

struksi identitas yang ia miliki, baik secara sosial maupun kultural (Setyaningrum, 2005: 19). Dari dua pandangan ini, dapat ditarik suatu definisi bahwa politik identitas merujuk pada praktik politik yang didasarkan pada pemanfaatan kesadaran akan kesamaan identitas tertentu, seperti; warna kulit, jenis kelamin, agama, budaya, pekerjaan, etnis, ras, dan usia.

Politik identitas pada dasarnya memiliki perbedaan dengan politik aliran yang kembali populer di era pasca reformasi. Politik aliran merujuk pada kelompok-kelompok sosio-budaya yang berkembang dari pembelahan kultural masyarakat Jawa ala Geertz (santri, priyayi, dan abangan) dan kemudian menjelma sebagai organisasi politik dengan menganut arah serta posisi ideologis yang sama (Alatas, 2010: 39). Sementara politik identitas cenderung mengedepankan kesamaan identitas terlepas dari adanya implikasi bahwa kesamaan identitas memiliki kesamaan arah dan posisi ideologis. Praktik politik aliran pada Pemilu 2009 menyebabkan kontestasi yang tajam antara partai-partai nasionalis dengan partai Islam.

Politik identitas seyogyanya merupakan strategi dalam politik, yang apabila dipraktikkan dapat berarti baik atau buruk, tergantung siapa, bagaimana, dan untuk tujuan apa politik ini dimanfaatkan (Setyaningrum, 2005; Appiah, 2006; Ma'arif, 2012; Xiaomei, 2014). Penggunaan politik identitas sebagai strategi pada dasarnya memiliki tujuan yang fundamental, seperti membela dan memperjuangkan kepentingan kelompok-kelompok tertentu yang tertindas karena identitas yang dimilikinya (Appriah, 2006: 15). Akan tetapi persoalan yang terjadi di Indonesia menurut Siti Musdah Mulia (dalam Ma'arif, 2012: 45) ini dilakukan oleh kelompok mainstream, yaitu kelompok mayoritas, dengan niat "menyingkirkan" kaum minoritas yang dianggapnya "menyimpang" atau "menyeleweng". Terlebih karena proses desentralisasi dan otonomi daerah mendorong penguatan identitas kultural dan sentimen kedaerahan, yang apabila tidak diantisipasi bukan hanya akan menumbuhkan sentimen local-nationalism yang dapat tumpang tindih dengan ethnonationalism, tetapi juga menghilangkan posisi sentral Pancasila sebagai identitas nasional baik langsung maupun tidak langsung (Azyumardi Azra dalam Fikri dan Octario, 2018: 183).

Pada proses pergantian kepemimpinan, politik identitas cenderung dimaksudkan untuk mengarahkan pilihan kepada calon pemimpin yang memiliki kesamaan identitas dengan mereka, baik identitas agama, etnis, warna kulit, jenis kelamin, budaya, pekerjaan, ras, dan usia. Dalam praktiknya, politik identitas dihembuskan oleh seorang elit terhadap kelompok mayoritas untuk memperoleh legitimasi dalam setiap tindakan politiknya, sementara di sisi lain digunakan oleh kelompok tersebut untuk menentukan pilihan berdasarkan kesamaan-kesamaan identitas ter- 
tentu (Maarif, 2012; Xiaomei, 2014; Fikri dan Octario, 2018).

Praktik ini menimbulkan reaksi negatif dan penolakan dari kelompok minoritas, terutama dalam proses pergantian kekuasaan baik di tingkat nasional maupun daerah. Secara moral praktik politik identitas dalam pergantian kepemimpinan dinilai buruk, karena pemimpin yang terpilih karena praktik politik identitas dianggap seringkali mengeluarkan kebijakan yang tidak berimbang, berat sebelah, memihak pada satu sisi dan memarjinalkan sisi lainnya sehingga berpotensi memunculkan konflik horizontal pada tataran tertentu (Ma'arif, 2012). Terlebih lagi, pemimpin terpilih dikhawatirkan hanyalah sebatas simbol keislaman dan tidak memiliki keunggulan dalam kapasitasnya. Tetapi dari sudut pandang yang berbeda, praktik politik identitas dinilai relevan dan fungsional sehingga hampir setiap orang kini melakukannya. Ini senada dengan pendapat Chandrakirana dalam Haboddin (2012) yang mengatakan bahwa Politik identitas biasanya digunakan oleh para pemimpin sebagai retorika politik sekedar untuk dijadikan alat memanipulasi -alat untuk menggalang politikguna memenuhi kepentingan ekonomi dan politiknya.

Sebagaimana juga yang dikemukakan oleh Fikri dan Octario (2018: 177) bahwa praktik ini menjadi mungkin karena identitas masih dapat digunakan sebagai acuan dan konsolidator demokrasi, itu sebabnya para elit saat ini cenderung membawa isu-isu yang berkaitan dengan identitas dalam politik praktis yang dijalankannya dalam rangka untuk meraup suara sebanyakbanyaknya dari masyarakat. Terlebih lagi, politik identitas biasanya tidak lepas dari kampanye negatif dan kampanye hitam yang bertujuan untuk merusak citra diri lawan politik dan mengalihkan perhatian para pemilih (Ahmad, 2008; Sopian, 2011).

\section{Reproduksi Politik Identitas di Media Daring}

Berdasarkan penelusuran yang dilakukan terhadap beberapa media daring nasional, ditemukan bahwa reproduksi politik identitas yang mempengaruhi kecenderungan afiliasi suara pemilih Muslim dalam pemilihan Gubernur Sumatra Utara tahun 2018 terbagi atas tiga tipologi, diantaranya: 1) pembenturan antara Islam dengan "kafir" (penganut agama lain), 2) membangkitkan kembali sentimen pribumi dan non pribumi, serta 3) reproduksi politik identitas melalui kampanye negatif dan kampanye hitam. Tiga tipologi ini diperoleh dari hasil penelusuran internet (internet searching) terhadap 38 laman berita yang menampilkan informasi terkait Pemilihan Gubernur Sumatra Utara Tahun 2018. Berikut ini merupakan penjabarannya.
Tabel 3. Reproduksi Politik Identitas dalam Media Daring dengan kata kunci "Politik Identitas Pilgub Sumatera Utara Tahun 2018"

\begin{tabular}{lllrc}
\hline No & \multicolumn{1}{c}{ Tipologi } & $\mathrm{f}$ & $\%$ \\
\hline 1 & $\begin{array}{l}\text { Pembenturan Identitas antara Islam } \\
\text { dengan Penganut agama lain }\end{array}$ & 15 & 39,5 \\
2 & $\begin{array}{l}\text { Membangkitkan sentimen Pribumi } \\
\text { dengan Non pribumi }\end{array}$ & 12 & 31,6 \\
3 & $\begin{array}{l}\text { Repoduksi politik identitas melalui } \\
\text { kampanye negatif dan kampanye }\end{array}$ & 7 & 18,4 \\
& $\begin{array}{l}\text { hitam } \\
\text { Lain-lain }\end{array}$ & 4 & 10,5 \\
\hline & Jumlah & 38 & 100 \\
\hline
\end{tabular}

Sumber: Data primer

Data di atas menunjukkan bahwa reproduksi politik identitas dalam kampanye politik lebih sering muncul dalam bentuk pembenturan kelompok identitas antara Islam dengan penganut agama lain, serta dengan membangkitkan sentimen pribumi dengan non pribumi. Kedua tipologi ini memperlihatkan adanya suatu pola pendulangan suara yang memanfaatkan kontestasi antara kelompok mayoritas dengan kelompok minoritas, baik antara umat Islam $(66,1 \%)$ dengan non muslim $(33,9 \%)$ maupun antara kelompok pribumi $(89,4 \%)$ dengan non pribumi $(10,6 \%)$. Oleh karenanya, identitas etnis dan agama kedua pasang calon seolah lebih diutamakan dibanding kapasitas, kapabilitas, prestasi, dan rekam jejak mereka.

\section{Identitas Agama: Islam dengan "Kafir"}

Isu agama merupakan isu yang sangat sensitif di Indonesia, khususnya di Sumatra Utara. Sejak awal diberlakukannya sistem pemilihan langsung untuk kepala daerah, isu ini selalu muncul ke permukaan dan direproduksi dalam beragam bentuk dan rupa.

Pada pemilihan kepala daerah beberapa periode sebelumnya, isu agama sebenarnya sudah dimanfaatkan oleh para pendukung masingmasing kandidat, hanya saja intensitasnya tidak lebih tinggi dibandingkan dengan pemilihan tahun 2018. Hal ini dikarenakan pada pemilihan sebelumnya setiap pasangan calon pemimpin terdiri atas komposisi Muslim dan Non Muslim. Selama model "pelangi" ini diterapkan, tensi politik memang memanas tetapi tidak sampai mengganggu kerukunan dalam relasi antarumat beragama di Sumatra Utara. Akan tetapi pada pemilihan Gubernur Sumatra Utara tahun 2018, isu identitas agama kembali direproduksi sebagai bagian dari strategi politik. Isu ini bahkan dianggap sebagai perluasan dari gerakan 411 dan 212 pasca insiden Al-Maidah 51 oleh Ahok, yang juga dikaitkan dengan euforia kontestasi pemilihan Gubernur Jakarta tahun 2017 sebagai isu sentral ${ }^{4}$.

Insiden Al-Maidah 51 dan gejolak sosial yang mewarnainya merubah banyak hal di Sumatra

\footnotetext{
${ }^{4}$ Rujuk pada tauran berikut:

https://www.bbc.com/indonesia/indonesia-44601789
} 
Utara, dimana kelompok etnis yang dahulunya satu oleh sistem kekerabatan mulai terpecahpecah karena isu agama. Kondisi ini mengakibatkan kerenggangan ikatan antara Siregar Islam dengan Siregar Kristen, Saragih Islam dengan Saragih Kristen, Tarigan Islam dengan Tarigan Kristen dan sebagainya. Padahal, di masa lalu masyarakat yang terikat dengan sistem kekerabatan cenderung tidak mempersoalkan perbedaan agama yang dianut. Mereka menjaga kerukunan dalam ikatan kekerabatan (dalihan na tolu) bahkan sampai mereka mati, bahkan dalam beberapa situasi mereka lebih marah jika dikatakan "tidak beradat" daripada "tidak beragama" (Angga, 2017: 193).

Kenyataan yang terjadi saat ini justru sangat berbeda dibanding dulu. Kampanye memang tidak lagi dilakukan di tempat ibadah melainkan di ruang publik seperti lapangan dan media sosial (youtube, facebook, dan sebagainya), tetapi hal itu merubah sesuatu yang sifatnya eksklusif menjadi inklusif dan mempertajam perbedaan pilihan yang dianut masyarakat. Penggunaan isu kafir sebagai bentuk reproduksi politik identitas memisahkan ikatan kekerabatan yang sudah terjalin sejak lama, doktrin-doktrin agama di kedua sisi seolah memaksa orang memilih antara surga dan neraka. Proses pemilihan kepala daerah dianggap sebagai perang simbolis antara kebajikan dan keburukan, sehingga muncul terminologi "Partai Allah vs Partai Setan" yang dilontarkan oleh salah satu tokoh nasional Indonesia ${ }^{5}$.

Keterlibatan tokoh agama seperti ustadz dan ulama sebagai patron untuk meraih suara dinilai sangat berpengaruh, sebab keberadaan patron menjadi referensi spiritual bagi pemilih Muslim dalam menetapkan pilihannya berdasarkan kesamaan identitas agama. Dalam kasus pemilihan gubernur Sumatra Utara tahun 2018, para ulama merasionalisasikan pemimpin muslim yang peduli pada Islam sebagai figur ideal yang harus dipilih oleh umat Islam. Pendapat ini juga dikuatkan oleh penelitian Marzuki (2019), bahwa ustadz dan ulama memiliki kontribusi yang cukup besar dalam pemenangan Edy Rahmayadi dan Musa Rajeckshah.

Para ulama menilai bahwa penistaan yang selama ini terjadi dikarenakan Indonesia dipimpin oleh pemimpin yang tidak peduli pada Islam. Oleh karenanya, para ulama menekankan bahwa umat Islam harus memilih pemimpin yang peduli dengan Islam ${ }^{6,7}$. Meski tidak secara spesifik mengarahkan, tetapi pemilih muslim dapat menafsirkan bahwa orang-orang yang dikatakan peduli dengan Islam adalah pasangan Edy

\footnotetext{
5 Rujuk pada tautan berikut: https://www. cnnindonesia.com/nasional/20180413144201-32-

290626/amien-rais-dikotomikan-partai-setan-dan-partai-allah

6 Lihat videonya pada tautan berikut: https://www. youtube.com/watch?v=OQSPdAFhbUE

Lihat videonya pada tautan berikut: https://www. youtube.com/watch?v=C9GsxiTd0zE
}

Rahmayadi dan Musa Rajeckshah, yang berlatar belakang Islam-Islam, berasal dari partai yang didukung oleh para ulama, dan bersedia menandatangani pakta integritas dengan para ulama ${ }^{8}$.

Sebutlah Ustadz Abdul Somad, yang meski tidak menunjukkan keberpihakannya pada salah satu calon secara spesifik, dalam potongan video ceramahnya menganjurkan bahwa umat Islam harus memilih pemimpin Muslim sebagai aturan yang bersumber dari Al Qur'an. la menganalogikan pasangan Calon Gubernur dan Gubernur sebagai gulai ${ }^{9}$, dimana gulai yang boleh dimakan adalah gulai "kentang dengan daging yang halal" sementara gulai yang tidak boleh dimakan adalah "kentang dengan daging yang tidak halal"10.

Ceramah ini oleh sebagian besar umat Islam ditafsirkan sebagai petunjuk bahwa pemimpin ideal adalah pemimpin yang beragama Islam, baik kepala daerah maupun wakilnya. Kemudian, beredar juga pesan Ustadz Adi Hidayat, yang menyampaikan bahwa pemilih Muslim boleh saja sepakat tidak memilih, sebab itu merupakan hak azasi seseorang dalam demokrasi. Tetapi persoalannya ketika orang Muslim tidak memilih, orang liberal memilih, orang sekuler memilih, lesbi ikut memilih, homoseksual memilih. Ketika suara mereka banyak, mereka yang memegang kekuasaan""11.

\section{Identitas Pribumi vs Non Pribumi}

Di Sumatra Utara, proses pemilihan Kepala Daerah tidak dapat sepenuhnya lepas dari isu kedaerahan, khususnya dalam terminologi identitas pribumi dan non pribumi (Burhan dan Sany, 2013; Faraidiany, 2016). Setiap kali pemilihan diadakan, wacana pribumi dan non pribumi selalu menjadi ukuran layak atau tidaknya seseorang menjadi pemimpin di Sumatra Utara, bahwa konsep pemimpin ideal direproduksi sebagai sosok keturunan pribumi yang menunjukkan keberpihakannya pada kaum pribumi melalui sikap politiknya (Muda, 2013; 142). Kecenderungan ini yang akhirnya membuat Sofyan Tan, seorang tokoh masyarakat Tionghoa, mengurungkan niatnya untuk bertarung di Pemilihan Gubernur Sumatra Utara tahun $2018^{12}$.

Lebih lanjut, Edy Rahmayadi adalah figur seorang keturunan Melayu dan Jawa kelahiran Aceh, selain itu ia pernah menduduki posisi strategis di Sumatra Utara selama karir mili-

\footnotetext{
${ }^{8}$ Rujuk beritanya pada tautan berikut: https://kumparan. com/gun_gun-gunadi/gnpf-ulama-sumut-komitmen-dukungeramas-1522137746209

9 Jenis makanan khas Melayu dengan kuah santan berwarna kuning

${ }^{10}$ Lihat videonya pada tautan berikut: https://www.youtube. com/watch?v=2BIOTF24hq0

${ }^{11}$ Lihat videonya pada tautan berikut: https://www.youtube. com/watch? $v=X 47 \mathrm{clB9AKKw}$

12 Rujuk pada tautan: https://www.rmol.col read/2016/04/03/241823/Maju-Di-Pilkada-Sumut,-Sofyan-

Tan-Pasti-Punya-Hitung-hitungan-
} 
ternya. Latar belakang sebagai prajurit militer menghadirkan citra bahwa ia memiliki rasa nasionalisme yang tidak dapat diragukan. Sebenarnya jika dilihat dari tempat kelahiran, ia adalah seorang "pendatang". Tetapi karena ia keturunan Melayu, nasionalis, dan juga menunjukkan sikap keberpihakan politik pada pribumi, ia pun dianggap oleh pemilih Muslim sebagai pribumi dan putra daerah ${ }^{13}$.

Sementara itu, Djarot adalah keturunan Jawa asli, seorang politisi yang dianggap memiliki cukup pengalaman untuk menjalankan pemerintahan di tingkat provinsi. Kolaborasinya dengan Ahok selama memerintah DKI Jakarta dianggap berhasil oleh sebagian kalangan, akan tetapi ia bukan orang asli Sumatra Utara dan kerap dilabeli sebagai "pendatang" sehingga menyulitkan langkahnya untuk meraih suara di beberapa kabupaten kota ${ }^{14}$. Terlebih lagi, polemik Reklamasi Teluk Jakarta membuat ia dikaitkan oleh sebagian pemilih Muslim sebagai bagian dari kelompok 3A, yakni Asing, Aseng, dan Antek ${ }^{15}$.

Sejak dahulu, terminologi pribumi dan non pribumi memang masih menjadi isu yang sensitif di Sumatra Utara, apalagi jika isu tersebut kerap dikaitkan dengan eksistensi warga keturunan Tionghoa $^{16}$. Warga keturunan Tionghoa di Sumatra Utara dinilai sebagai komunitas yang eksklusif, segregatif, tidak loyal terhadap NKRI, jaringan sosial yang sangat tertutup, dan selalu memandang rendah kaum pribumi khususnya umat islam bahkan hingga kini (Faraidiany, 2015; Harahap dan Abdurrahman, 2014). Beberapa kali muncul gejolak dalam relasi mereka baik dalam skala kecil (konflik dalam kehidupan sehari-hari) maupun yang berskala besar seperti di tahun 1965 dan 1998. Kasus terakhir adalah miskomunikasi terkait protes adzan yang berujung pada insiden pembakaran vihara karena meledaknya amarah warga di Tanjungbalai (Susanto, 2018).

Para pemilih Muslim di Sumatra Utara memahami bahwa etnis Tionghoa menguasai sektor perekomian di berbagai bidang, sektor yang cukup vital dimana sebagian besar masyarakat menggantungkan hidupnya dari sini. Di satu sisi keunggulan ini menciptakan privilege tersendiri yang menguntungkan bagi etnis Tionghoa, namun di sisi lain ini juga menciptakan kecemburuan sosial dan prasangka bagi kelompok etnis lain (Putra, 2010).

Pendapat ini dibuktikan dengan hasil penelitian Burhan (2013: 30), yang menunjukkan

\footnotetext{
13 Rujuk pada tautan berikut: https://www.bbc.com/ indonesia/indonesia-44601789

Rujuk pada tautan berikut: https://www.bbc.com/ indonesia/indonesia-42493569

${ }^{15}$ Asing merujuk pada negara lain, Aseng merujuk pada WNI keturunan Cina, dan Antek Merujuk pada orang-orang "pribumi" yang bekerja atau dimanfaatkan oleh Asing dan Aseng untuk kepentingan tertentu.

${ }^{16}$ Rujuk pada tautan berikut: https://tirto.id/sejarah-kebencianterhadap-etnis-tionghoa-bFL $p$
}

$241 \mid \mathrm{P}$ a $\mathrm{g}$ e

https://doi.org/10.25077/ jantro.v22.n2.p236-244.2019 bahwa keberadaan etnis Tionghoa kerap dianggap sebagai ancaman bagi etnis pribumi, baik itu ancaman yang bersifat simbolik (ancaman terhadap nilai-nilai, moral, budaya) maupun yang bersifat realistik (ancaman terhadap kesejahteraan hidup, seperti; kekuatan politik, ekonomi, dan sumber daya). Padahal di daerah lain seperti di Solo, relasi antara etnis Tionghoa dengan etnis lain berjalan lebih mulus dan integrasi sosial terwujud dalam berbagai aspek (Purbasari dan Suharno, 2019).

Insiden "Al Maidah 51" oleh mantan Gubernur Ahok beberapa tahun silam menjadi pintu masuk pemanfaatan sentimen pribumi versus non pribumi dalam pemilihan Gubernur serentak tahun 2018 (Sutisna dan Akbar, 2018). Pernyataan tersebut dilihat sebagai pernyataan simbolik oleh Ahok yang beretnis Tiongha dan dianggap sebagai bentuk dominasi minoritas non pribumi terhadap kelompok pribumi yang mayoritas beragama Islam. Serangkaian isu ini menjadi medium yang tepat untuk mematahkan strategi politik Djarot-Sihar dalam meraih suara pemilih Muslim di Sumatra Utara. Sebab selain karena Djarot adalah mantan rekan kerja Ahok, ia juga diusung oleh partai yang dianggap tidak pernah memihak umat Islam. Sementara di sisi lain, wakilnya pun bukan berasal dari kalangan umat Islam.

Beberapa hal yang sudah disebutkan di atas menjadi referensi yang kuat bagi elit untuk membangun rasionalitas agar umat Islam tidak memilih pemimpin yang bukan Islam serta pemimpin yang tidak berpihak pada pribumi. Sebab ketika pemimpin seperti itu terpilih, kebijakan yang akan diambil dikhawatirkan tidak akan pernah berpihak kepada umat Islam seperti yang terjadi di Kalimantan Barat, Nusa Tenggara Timur, Papua, Manado, serta daerah-daerah lain yang muncul di berbagai media karena mendiskreditkan agama Islam dan umat muslim.

Pengalaman yang terjadi di daerah lain menciptakan rasa tidak percaya pemilih Muslim di Sumatra Utara terhadap kepemimpinan yang dianggap tidak fair. Selain itu, perasaaan tersebut juga muncul terhadap kepemimpinan yang dianggap mengancam nilai-nilai keislaman karena pengaruh dari orang-orang yang berada di lingkaran kekuasaan, seperti; pembatasan adzan, dukungan terhadap LGBT, dukungan terhadap ideologi komunis, pembiaran atas kasus penistaan agama, identifikasi Islam sebagai ideologi radikal, dan sebagainya.

\section{Kampanye Hitam dan Kampanye Negatif}

Pemilihan Calon Gubernur di Sumatra Utara tahun 2018 silam juga diwarnai dengan serangkaian kampanye negatif dan kampanye hitam. Kampanye negatif ini oleh Ahmad (2008: 2) dimaknai sebagai informasi yang benar tetapi sifatnya negatif terkait dengan identitas kandidat (bisa dugaan korupsi, karakter, sejarah masa lalu, keluarga dsb) yang didasarkan pada fakta, 
sementara kampanye hitam tidak didasarkan atas data dan fakta (hoax). Kedua jenis kampanye ini biasanya dilakukan oleh elit tertentu untuk mengesankan citra diri yang baik dengan cara menciptakan citra buruk kepada lawannya. Pada praktik ini, peran media menjadi sangat penting khususnya dalam menyampaikan pesan-pesan politik kepada para konstituen atau pemilih.

Kedua kandidat mengakui bahwa mereka menjadi korban kampanye hitam dan kampanye negatif pada Pilkada Sumatra Utara tahun 2018. Edy Rahmayadi misalnya, ia diisukan terkena serangan stroke sehingga tidak mampu melanjutkan pencalonan dirinya sebagai Gubernur Sumatra Utara, padahal kenyataannya ia sedang melaksanakan Umroh ${ }^{17}$. Dari beberapa media yang ditelusuri tidak diketahui pasti siapa yang pertama kali menyebarkan, tetapi isu ini bertujuan untuk mengarahkan para pemilih untuk tidak memilih pemimpin yang sakit. Isu lain yang berkembang adalah pembaptisan Edy Rahmayadi oleh pendeta Kristen ${ }^{18}$ dan isu tentang dugaan kedekatannya dengan Sekjen PSSI, Ratu Tisha Destria ${ }^{19}$.

Di lain pihak, Djarot juga mengaku mengalami hal yang sama. Dalam pengakuannya, ia mengatakan bahwa ada tudingan pemilihan Gubernur hanya batu loncatan untuk menduduki posisi Menteri di pemerintahan yang sekarang ${ }^{20}$. Secara otomatis, ini akan menghantarkan Sihar Sitorus menjadi Gubernur untuk mengisi kekosongan jabatan yang ditinggalkan oleh Djarot nantinya $^{21}$. Berdasarkan pengalaman polemik yang muncul akibat kepemimpinan Ahok di Jakarta, para pemilih muslim di Sumatra Utara cenderung bersikap tegas dan tidak menginginkan polemik yang sama kembali terulang.

Meski sejak awal program-program yang diutarakan oleh Djarot-Sihar dinilai cukup populis dan memiliki nilai jual tinggi untuk mendongkrak elektabilitas, pengalaman terdahulu membuat pemilih Muslim seolah tidak lagi melihat hal itu sebagai sesuatu yang penting. Lebih jauh, Djarot juga sempat ditimpa isu miring tentang praktik politik uang yang ia lakukan di sela agenda kampanye ${ }^{22}$. Selain itu, isu politik uang juga kian

\footnotetext{
17 Rujuk pada tautan berikut: https://www.antaranews. com/berita/716597/edy-rahmayadi-mengaku-seringmendapat-fitnah

${ }_{8}$ Rujuk pada tautan berikut: https://www.jawapos. com/nasional/pemilihan/10/05/2018/pendeta-bantah-baptisedy-rahmayadi/

19 Rujuk pada tautan berikut: http://jateng.tribunnews. com/2018/12/06/edy-rahmayadi-bantah-punya-hubungandekat-dengan-ratu-tisha-kasihan-dia-dia-yang-rugi?page=3

20 Rujuk pada tautan berikut: https://regional.kompas. com/read/2018/04/12/08084891/djarot-kepada-yangmemfitnah-saya-berdoa-ampuni-mereka-tuhan

21 Rujuk pada tautan berikut: https://pilkada.tempo.co /read/1083350/djarot-saiful-hidayat-minta-dai-beri-pendidikanpolitik-ke-umat/full\&view=ok

${ }_{22}$ Rujuk pada tautan berikut: https://www.liputan6.com /pilkada/read/3502727/kuasa-hukum-djarot-saiful-hidayattudingan-politik-uang-fitnah
}

menguat dengan digagalkannya dugaan serangan fajar melalui pembagian sembako oleh mantan Gubernur Syamsul Arifin di Kota Medan $^{23}$

Tidak hanya calon Gubernur, isu miring juga menimpa kedua calon Wakil Gubernur. Untuk ljeck misalnya, ia diisukan tersangkut dugaan kasus alih lahan yang dilakukan oleh perusahaan keluarga (PT. ALAM) di masa lalu ${ }^{24}$. Sementara untuk Sihar sendiri, kasus alih fungsi lahan Register 40 dari hutan lindung menjadi lahan perkebunan menjadi batu sandungan yang sangat menyulitkan baginya ${ }^{25}$.

Lebih lanjut, informasi dalam kampanye hitam maupun kampanye negatif pada dasarnya sangat mempengaruhi preferensi masyarakat untuk memilih kandidat mana yang mereka percayai sebagai pemimpin (Ahmad, 2008: 3). Akan tetapi, baik kampanye hitam maupun kampanye negatif hanya berhasil pada tokoh yang tidak dikenal baik oleh masyarakatnya. Selain itu, bentuk kampanye ini juga hanya berpengaruh pada swing voter. Jika masyarakat mengenal baik sosok dari tokoh tersebut, kampanye hitam dan kampanye negatif justru hanya akan menimbulkan rasa simpati dan semakin menguatkan karakter tokoh tersebut di mata pemilihnya (Sopian, 2011: 93).

\section{KESIMPULAN}

$\mathrm{D}$ ilihat sebagai sebuah strategi untuk mewujudkan sebuah tujuan tertentu, politik identitas masih relevan diterapkan di Indonesia. Mengingat dalam demokrasi nasib suatu bangsa ditentukan oleh suara terbanyak, maka sudah sewajarnya kepentingan orang banyak harus lebih diutamakan untuk membangun bangsa dengan latar budaya yang lebih kuat. Tetapi jika dilihat dari perspektif berbeda, praktik politik identitas sebaiknya dihindari karena dianggap dapat mengancam pluralisme dan demokrasi yang multikultur di Indonesia.

Bagi pemilih Muslim, politik identitas masih relevan digunakan dalam Pemilihan Umum, baik di tingkat daerah maupun di tingkat nasional. Pilihan yang dianggap rasional adalah memilih orang yang sama latar belakang identitasnya, yakni putra daerah dan beragama Islam. Mereka melihat bahwa beberapa tahun terakhir kepemimpinan yang sedang berjalan tidak memihak pada umat Islam sebagai kelompok mayoritas sehingga memilih pemimpin yang seagama

\footnotetext{
23 Rujuk pada tautan berikut: http://medan.tribunnews. com/2018/06/26/ini-klarifikasi-syamsul-arifin-soal-rencanabagi-bagi-sembako-di-jalan-puri?page $=2$

24 https://www.cnnindonesia.com/nasional/2019020720471112-367345/kasus-lahan-wagub-ijeck-klaim-sudah-lamatinggalkan-pt-alam

${ }_{25}$ Rujuk pada tautan berikut: http://waspadamedan.com/ index.php/2018/05/10/keluarga-dl-sitorus-harus-segeraserahkan-lahan-register-40-ke-pemerintah/
} 
menjadi sangat penting. Tentunya apa yang dikemukakan oleh Caplan (2008) bahwa pemilihan umum yang ditentukan oleh pemilih atas dasar rasionalitas adalah sebuah mitos sedikit terbantahkan oleh kasus yang terjadi pada pemilihan kepala daerah Sumatra Utara tahun 2018, dimana politik identitas justru direproduksi berdasarkan rasionalitas yang dibangun untuk kepentingan kelompok yang lebih besar. Sementara itu, bentuk politik identitas dalam pemilihan gubernur Sumatra Utara tahun 2018 dilakukan dengan cara membenturkan antara umat Islam dengan penganut agama lain, membangkitkan kembali sentimen pribumi dan non pribumi, penyebaran kampanye negatif dan kampanye hitam, serta pemanfaatan patronisme dalam agama Islam.

\section{E. UCAPAN TERIMAKASIH}

U capan terimakasih penulis ucapkan kepada Direkrotat Jenderal Kebudayaan atas kesempatan yang telah diberikan, baik dalam bentuk pemberian Tugas Belajar maupun pembiayaan selama masa studi melalui jalur beasiswa Kerjasama Dirjen Kebudayaan dengan FIB UGM, sehingga penulis dapat menimba ilmu di kampus yang diimpikan sejak dulu. Tak lupa penulis sampaikan pula kepada pimpinan, Ibu Irini Dewi Wanti, S.S., M.SP atas segala dukungan dan rekomendasi yang telah diberikan. Terkhusus kepada Prof. Dr. Irwan Abdullah, terimakasih atas motivasi, inspirasi, bimbingan dan pelatihan yang telah diberikan. Kiranya tulisan ini merupakan yang pertama dan menjadi titik tolak bagi penulis untuk memulai tulisan-tulisan lain yang lebih berkualitas di masa yang akan datang. Semoga ilmu yang diajarkan dapat menjadi amal jariyah bagi beliau.

\section{DAFTAR PUSTAKA}

Ahmad, Nyarwi. (2008). Kampanye Negatif dalam Pilkada: Kajian Bulanan No.11 Maret 2008. Jakarta: PT. Lingkaran Survey Indonesia.

Alatas, Salim. (2010). Politik Aliran dalam Pemilu 2009 (Studi atas Political Marketing Partai Keadilan Sejahtera). Jurnal Kom dan Realitas Sosial. 1 (1): 37-48.

Angga. (2017). Rukun Sampai Mati: Dalihan na Tolu sebagai Wadah Relasi Antar Umat Beragama yang Toleran. Prosiding Seminar Nasional, 17-20 Juli 2019 dengan tema "Merajut Kebhinekaan, Membangun Indonesia: Perspektif Sejarah dan Budaya". Yogyakarta: Balai Pelestarian Nilai Budaya DIY.

Appiah, Kwame Anthony (2006), The Politics of Identity, Daedalus, 135 (4): 15-22.

Burhan, O. K., \& Sani, J. (2013). Prasangka Terhadap Etnis Tionghoa di Kota Medan: Peran Identitas Nasional dan Persepsi Ancaman. Jurnal Psikologia. 8 (1): 25-33.

Caplan, Bryan. (2008). The Myth of the Rational Voter Why Democracies Choose Bad Policies - New Edition. New Jersey: Princeton University Press.

Faraidiany, Maghfira. (2016). Politik Identitas Etnis Tionghoa di Indonesia. Jurnal Politeia. 8 (2): 74-82.

Fikri, M. Sirajudin \& Oktario, Nico A. (2018). Politik Identitas dan Penguatan Demokrasi Lokal (Kekuatan Wong Kito dalam Demokrasi Lokal). Tamaddun: Jurnal Kebudayaan dan Sastra Islam. 18 (2): 172-185.

Haboddin, Muhtar. (2012). Menguatnya Politik Identitas di Ranah Lokal. Jurnal Studi Pemerintahan. 3 (1): 116-134.

Harahap, Abdi Syahrial dan Abdurrahman, Syed. (2014). Etnik Tionghoa di Bandaraya Medan: Kajian Tentang Pandangan Mereka Terhadap Agama Islam. Jurnal Analytica Islamica. 3 (1): 134151.

Presiden Republik Indonesia. (1998). Instruksi Presiden Republik Indonesia Nomor 26 Tahun 1998 Tentang Menghentikan Penggunaan Istilah Pribumi dan Non Pribumi. Jakarta.

Ma'arif, Ahmad Syafii. (2012). Politik Identitas dan Masa Depan Pluralisme Kita. Jakarta: Democracy Project.

Marzuki. 2019. Kontribusi Ulama dalam Pemenangan Pasangan Edy Rahmayadi-Musa Rajekshah Pada Pemilihan Gubernur Sumatera Utara Tahun 2018 di Kota Medan. Tesis (Tidak Diterbitkan). Medan: UIN Sumatra Utara.

Muda, Indra. 2013. Potensi Konflik Horizontal di Kota Medan. Jurnal Perspektif. 6 (2): 138-144.

Purbasari, Verbena Ayuningsih dan Suharno. (2019). Interaksi Sosial Etnis Cina-Jawa Kota Surakarta. Jurnal Antropologi: Isu-Isu Sosial Budaya. 21 (1): 1-9.

Purnaweni, Hartuti. 2004. Demokrasi Indonesia: Dari Masa ke Masa. Jurnal Administrasi Publik. 3, (2): 118-131. 
Putra, Dharma Kelana. (2010). Potensi Konflik Komunitas Jawa Muslim Terhadap Etnis Berbeda dan Penganut Agama Lain di Kota Medan Tahun 2010. Skripsi (Tidak Diterbitkan). Medan: Universitas Sumatra Utara.

Sopian. (2011). Pengaruh Kampanye Negatif dalam Pemilihan Umum Kepala Daerah (Pemilukada) Tangerang Selatan (Tangsel) 2011. Skripsi (Tidak diterbitkan). Jakarta: Universitas Islam Negeri Syarif Hidayatullah.

Suparlan, Parsudi. (1994). Metode Penelitian Kualitatif. Jakarta: Universitas Indonesia Press.

Susanto, Agus. (2018). Pola Komunikasi Masyarakat Muslim Melayu dan Tionghoa (Studi Terhadap Penyelesaian Konflik di Kota Tanjungbalai). Tafaqquh: Jurnal Penelitian dan Kajian Keislaman. 6 (1): 2-27.

Sutisna, Agus \& Akbar, Idil. (2018). Dampak Elektoral Kasus Dugaan Penistaan Agama terhadap Preferensi Politik Warga Banten pada Pilgub 2018. Politik. 15 (2): 161-178.

Xiaomei, Zhan. (2014). Political Identity: A Perspective from Cultural Identity. Journal Social Sciences in China. 35 (2): 155-173. 